\title{
Response of Dry Bean to Sulfentrazone Plus Imazethapyr
}

\author{
Nader Soltani, Christy Shropshire, and Peter H. Sikkema \\ University of Guelph, Ridgetown Campus, 120 Main Street East, Ridgetown, ON, Canada NOP 2C0 \\ Correspondence should be addressed to Nader Soltani; soltanin@uoguelph.ca
}

Received 26 July 2013; Accepted 9 December 2013; Published 30 January 2014

Academic Editor: Silvia Imhoff

Copyright (c) 2014 Nader Soltani et al. This is an open access article distributed under the Creative Commons Attribution License, which permits unrestricted use, distribution, and reproduction in any medium, provided the original work is properly cited.

\begin{abstract}
Field studies were conducted in 2010 and 2011 at the Huron Research Station, Exeter, Ontario and from 2009 to 2011 at the University of Guelph Ridgetown Campus, Ridgetown, Ontario to evaluate the sensitivity of four market classes of dry bean to sulfentrazone applied preemergence at 105,140 , and $280 \mathrm{~g}$ ai/ha alone and in combination with imazethapyr at $37.5 \mathrm{~g}$ ai/ha. At 1 week after emergence (WAE), sulfentrazone alone or in combination with imazethapyr at all doses evaluated caused no significant visible injury in dry bean. At 2 WAE, sulfentrazone alone caused 1-11, 1-11, 1-5, and 3-19\% visible injury, and sulfentrazone + imazethapyr caused 3-11, 2-10, 2-5, and 4-20\% visible injury in black, cranberry, kidney, and white bean, respectively. At 4 WAE, sulfentrazone alone caused $1-7,1-7,0-4$, and $1-16 \%$ visible injury and sulfentrazone + imazethapyr caused 1-8, 1-5, 1-3, and 2-14\% visible injury in black, cranberry, kidney, and white bean, respectively. Sulfentrazone PRE caused slightly greater injury in black and white bean compared to cranberry and kidney bean. Generally, crop injury with sulfentrazone at rates up to $140 \mathrm{~g}$ ai/ha alone and in combination with imazethapyr at $37.5 \mathrm{~g}$ ai/ha was minimal with no adverse effect on plant height, shoot dry weight, seed moisture content, and yield. Based on these results, there is potential for preemergence application of sulfentrazone at rates up to $140 \mathrm{~g}$ ai/ha alone or in combination with imazethapyr at $37.5 \mathrm{~g}$ ai/ha in black, cranberry, kidney and white bean.
\end{abstract}

\section{Introduction}

Dry bean is an important crop grown in Ontario. In 2012, dry bean growers seeded 46,500 hectares and produced 129,000 MT of dry bean with a farm-gate value of approximately $\$ 90$ million [1]. Major market classes of dry bean grown in Ontario include black, cranberry, kidney, and white (navy) bean. Dry bean is a short season crop with short physical stature and therefore is very sensitive to weed interference [2-6]. Weed interference has been shown to reduce seed yield of dry bean as much as 70\% [7]. Presence of weeds at the harvest time can also cause seed staining and interfere with harvesting efficiency in dry bean [8-11]. More research is needed to develop innovative precision weed management options that have an adequate margin of crop safety, provide consistent broad spectrum weed control, and maximize dry bean yield and net returns. Each year Ontario dry bean producers face a dilemma in respect to annual broadleaf weed control. Research has clearly demonstrated that the use of a broad spectrum soil applied herbicide program is the optimal approach to protect the crop during the critical period of weed control. The dilemma is there is only one soil applied herbicide with predominantly broadleaf weed activityimazethapyr. It is widely recognized that imazethapyr is a very efficacious soil applied broadleaf herbicide but it has a narrow margin of crop safety, especially in the small seeded market classes of dry beans, specifically white and black beans. White and black beans are two of the most widely grown market classes of dry beans in Ontario. More research is needed to identify new herbicide options or tankmix partners with imazethapyr that provide consistent broadleaf weed control and have an adequate margin of crop safety in different market classes of dry bean.

Sulfentrazone is a protoporphyrinogen oxidase (PPO) inhibitor herbicide for use in soybean (Glycine max) that can control many of the common annual broadleaf weeds that occur in Ontario such as common lambsquarters (Chenopodium album L.), redwood pigweed (Amaranthus retroflexus L.), velvetleaf (Abutilon theophrasti Medicus), common ragweed (Ambrosia artemisiifolia L.), common waterhemp (Amaranthus tuberculatus VAR. rudis), and eastern black nightshade (Solanum ptycanthum Dun. ex DC. pp.) 
[11-14]. Sulfentrazone can be soil applied as a preplant (PP), preplant incorporated (PPI), or preemergence (PRE) herbicide for broadleaf weed control $[15,16]$. Sulfentrazone is taken up by both the roots and foliage; however, it is primarily taken up by the roots in treated soils [14]. Sulfentrazone is registered at a rate of 150 to $400 \mathrm{~g} \mathrm{ha}^{-1}$ in soybean with the rate applied dependent on soil texture and organic matter. Susceptible plants in sulfentrazone treated soils show necrotic symptoms and die shortly after exposure to light [14].

There is little published data on the sensitivity of "Black Velvet" black bean, "T9905" white bean, "Etna” cranberry bean, and "Red Hawk" kidney bean to sulfentrazone alone or in combination with imazethapyr. Sulfentrazone alone or in combination with imazethapyr has the potential to provide acceptable control of troublesome annual broadleaf weeds with an acceptable margin of crop safety in dry bean. Tolerance of dry beans to various soil applied herbicides has been shown to be dependent by herbicide rate, market class, cultivar, and environmental conditions $[2,5,17,18]$.

The objective of this study was to evaluate the tolerance of black, cranberry, kidney, and white bean to sulfentrazone applied preemergence at 105, 140, and $280 \mathrm{~g}$ ai/ha alone and in combination with imazethapyr at $37.5 \mathrm{~g}$ ai/ha.

\section{Materials and Methods}

Field studies were conducted in 2010 and 2011 at the Huron Research Station, Exeter, Ontario, Canada and at 2009, 2010, and 2011 at the University of Guelph Ridgetown Campus, Ridgetown, Ontario, Canada. The soil at Exeter was a Brookston clay loam (Orthic Humic Gleysol, mixed, mesic, and poorly drained) with $32 \%$ sand, $42 \%$ silt, $26 \%$ clay, $3.7 \%$ organic matter, and $\mathrm{pH}$ of 7.8. The soil at Ridgetown was a Wattford (Grey-Brown Brunisolic, mixed, mesic, sandy, and imperfectly drained)-Brady (Gleyed Brunisolic Grey-Brown Luvisol, mixed, mesic, sandy, and imperfectly drained) sandy loam with $53 \%$ sand, $27 \%$ silt, $20 \%$ clay, $5.3 \%$ organic matter, and $\mathrm{pH}$ of 7.0. Seedbed preparation at all sites consisted of fall moldboard plowing followed by two passes with a field cultivator in the spring.

The experiments were established as a 2-way factorial design arranged in a completely randomized block with four replications. Factor 1 was dry bean market class ("Black Velvet" black bean, "T9905” white bean, "Etna” cranberry bean, and "Red Hawk" kidney bean) and Factor 2 was preemergence herbicide treatments. Preemergence herbicide treatments included an untreated weed-free control, sulfentrazone at 105,140 , and $280 \mathrm{~g}$ ai/ha, imazethapyr at $37.5 \mathrm{~g}$ ai/ha, and sulfentrazone plus imazethapyr at $105+37.5,140+37.5$, and $280+37.5 \mathrm{~g}$ ai/ha. Plots were $6 \mathrm{~m}$ wide $(8$ rows spaced $0.75 \mathrm{~m}$ apart) and $10 \mathrm{~m}$ long at Exeter and $8 \mathrm{~m}$ long at Ridgetown. Within each plot there were two rows of "Black Velvet" black bean, "T9905" white bean, "Etna" cranberry bean, and "Red Hawk" kidney bean. Beans were planted in late May to early June of each year.

Herbicide applications were made with a $\mathrm{CO}_{2}-$ pressurized backpack sprayer calibrated to deliver $200 \mathrm{~L} \mathrm{ha}^{-1}$ of spray solution at a pressure of $240 \mathrm{kPa}$ using ultra low drift nozzles (ULD120-02, Hypro, New Brighton, MN). Treatments were applied at one day after seeding and were left undisturbed on the surface of soil. All plots were maintained weed-free during the season with hand hoeing and cultivation as required.

Dry bean injury was visually estimated on a scale of 0 (no injury) to $100 \%$ (complete plant death) at 1,2 , and 4 weeks after crop emergence (WAE). Bean shoot dry weight was evaluated 4 WAE by cutting plants at the soil surface from $1 \mathrm{~m}$ of row per plot. Plants were dried at $60^{\circ} \mathrm{C}$ to a constant moisture and then weighed. Dry bean height was measured for 10 plants in each plot 6 WAE and the average height was recorded. Dry bean was considered mature when $90 \%$ of the pods in the weed-free check had turned from green to a golden colour. Beans were harvested from each plot with a small plot combine, yield, and seed moisture content were recorded, and yields were adjusted to $18 \%$ moisture.

Data were analyzed as a 2-way factorial using PROC MIXED in SAS 9.2. The two treatment factors, dry bean type and herbicide treatment, as well as their interaction were considered fixed effects, while environment (year-location combinations), interactions between environment and the fixed effects, and replicate nested within environment were considered random effects. Significance of fixed effects were tested using $F$-tests and random effects were tested using a $Z$ test of the variance estimate. Environments were combined for a given variable if the environment by bean type by herbicide interaction was not significant. The UNIVARIATE procedure was used to test data for normality and homogeneity of variance. For all injury ratings, the untreated check (assigned a value of zero) was excluded from the analysis. However, all values were compared independently to zero to evaluate treatment differences with the untreated check. To satisfy the assumptions of the variance analyses, injury $1 \mathrm{WAE}$ and seed moisture content were log transformed, and injury 2 and $4 \mathrm{WAE}$ were square root transformed. Treatment comparisons were made using Fisher's Protected LSD at a level of $P<0.05$. Additionally, contrasts were performed for each variable comparing (a) sulfentrazone versus sulfentrazone plus imazethapyr and (b) imazethapyr versus sulfentrazone plus imazethapyr. Data compared on the transformed scale were converted back to the original scale for presentation of results.

\section{Results and Discussion}

Environment by bean type by herbicide interaction was not significant for injury 1 and 4 WAE, shoot dry weight, height, seed moisture, and yield and all five datasets were analyzed together. Environment by bean type by herbicide interaction was significant for injury 2 WAE: Ridgetown 2010 was all zero (not shown in Table 1) and was separated from the rest. For main effects, bean Type was significant for yield; bean Type and Herbicide were significant for injury 2 and 4 WAE and height. Bean Type $\times$ Herbicide interaction was also significant for injury 2 and $4 \mathrm{WAE}$ and height. 
TABLE 1: Significance of main effects and interactions for percent visual injury, dry weight, height, seed moisture content, and yield of dry bean treated with PRE applications of sulfentrazone, imazethapyr, or sulfentrazone plus imazethapyr. Means followed by the same letter within a column are not significantly different according to Fisher's Protected LSD at $P<0.05$. Means for a main effect were separated only if there was no significant interaction involving that main effect ${ }^{\mathrm{a}}$.

\begin{tabular}{|c|c|c|c|c|c|c|c|}
\hline \multirow{2}{*}{ Main effects ${ }^{\mathrm{b}}$} & \multicolumn{3}{|c|}{ Dry bean injury } & \multirow{2}{*}{ Dry weight (g) } & \multirow{2}{*}{ Height $(\mathrm{cm})$} & \multirow{2}{*}{ Moisture (\%) } & \multirow{2}{*}{ Yield (T/ha) } \\
\hline & 1 WAE & $2 \operatorname{WAE}^{\mathrm{c}}(\%)$ & 4 WAE & & & & \\
\hline Type of dry bean & NS & $*$ & $*$ & NS & $* *$ & NS & $* *$ \\
\hline Black & 1 & 4 & 3 & 71 & 59 & 16.3 & $3.5^{\mathrm{a}}$ \\
\hline Cranberry & 1 & 4 & 2 & 72 & 51 & 18.0 & $1.7^{\mathrm{b}}$ \\
\hline Kidney & 1 & 2 & 1 & 73 & 53 & 18.7 & $1.9^{\mathrm{b}}$ \\
\hline White & 1 & 7 & 5 & 61 & 54 & 17.6 & $3.5^{\mathrm{a}}$ \\
\hline SE & 0 & 0 & 0 & 2 & 1 & 0.1 & 0.1 \\
\hline Herbicide treatment (rate in gai/ha) & NS & $* *$ & $* *$ & NS & $* *$ & NS & NS \\
\hline Untreated & 0 & 0 & 0 & 77 & 56 & 17.5 & 2.8 \\
\hline Sulfentrazone (105) & 0 & 2 & 1 & 72 & 55 & 17.9 & 2.7 \\
\hline Sulfentrazone (140) & 1 & 3 & 2 & 72 & 56 & 17.7 & 2.6 \\
\hline Sulfentrazone (280) & 2 & 11 & 8 & 63 & 53 & 18.0 & 2.6 \\
\hline Imazethapyr (37.5) & 0 & 1 & 1 & 66 & 55 & 17.3 & 2.7 \\
\hline Sulfentrazone + imazethapyr $(105+37.5)$ & 1 & 3 & 2 & 70 & 54 & 17.6 & 2.7 \\
\hline Sulfentrazone + imazethapyr $(140+37.5)$ & 1 & 4 & 3 & 70 & 54 & 17.4 & 2.6 \\
\hline Sulfentrazone + imazethapyr $(280+37.5)$ & 2 & 11 & 7 & 64 & 51 & 17.6 & 2.6 \\
\hline SE & 0 & 0 & 0 & 2 & 1 & 0.1 & 0.1 \\
\hline \multicolumn{8}{|l|}{ Interaction } \\
\hline $\mathrm{T} \times \mathrm{H}$ & NS & * & $* *$ & NS & * & NS & NS \\
\hline
\end{tabular}

Contrasts

Sulfentrazone versus sulfentrazone + imazethapyr

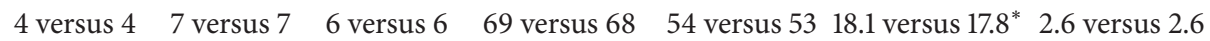

Imazethapyr versus sulfentrazone + imazethapyr

1 versus $4^{*} 2$ versus $7^{* *} 1$ versus $6^{*} \quad 66$ versus $68 \quad 55$ versus $53 \quad 17.6$ versus $17.8 \quad 2.7$ versus 2.6

${ }^{a}$ Abbreviations: WAE: week after crop emergence; H: herbicide treatment; NS: not significant at $P=0.05$ level; PRE: preemergence; T: type of dry bean.

${ }^{\mathrm{b}}$ Significance at $P<0.05$ and $P<0.01$ levels denoted by $*$ and $* *$, respectively.

${ }^{\mathrm{c}}$ Ridgetown 2010 values not included (all values zero, could not be combined with other environments).

3.1. Crop Injury. Injury symptoms evaluated visually included stunted growth, wrinkling of leaf tissue, leaf necrosis, leaf chlorosis, and leaf veinal discoloration. At $1 \mathrm{WAE}$, sulfentrazone alone or in combination with imazethapyr at doses evaluated caused no significant injury in black, cranberry, kidney, and white bean (Table 1). However, at 2 and 4 WAE, there was significant injury in dry bean with sulfentrazone alone or in combination with imazethapyr. At 2 WAE, sulfentrazone alone caused 1-11, 1-11, 1-5, and 3-19\% injury, and sulfentrazone + imazethapyr caused 3-11, 2-10, $2-5$, and $4-20 \%$ injury in black, cranberry, kidney, and white bean, respectively (Table 2 ). At $4 \mathrm{WAE}$, sulfentrazone alone caused $1-7,1-7,0-4$, and 1-16\% injury, and sulfentrazone + imazethapyr caused $1-8,1-5,1-3$, and $2-14 \%$ injury in black, cranberry, kidney, and white bean, respectively (Table 2 ). Imazethapyr alone at $37.5 \mathrm{~g}$ ai/ha did not cause any significant injury in black, cranberry, kidney and white bean at 2 and 4 WAE (Table 2). Contrasts indicated that adding imazethapyr to sulfentrazone did not increase injury in dry bean at 1,2, and 4 WAE (Table 1). However, adding sulfentrazone to imazethapyr increased injury 3,5 , and $5 \%$ at 1,2 , and
$4 \mathrm{WAE}$, respectively (Table 1$)$. In other studies, sulfentrazone applied PRE at higher rates ( 420 to $840 \mathrm{~g}$ ai/ha) caused up to $30 \%$ visible injury in black, brown, cranberry, kidney, otebo, pinto, white, and yellow eye bean [19]. The levels of injury in this study is similar to those seen with other PPO inhibitors such as fomesafen in dry bean [17, 20-22]. Sikkema et al. [20] also reported only $1 \%$ or less visible injury in dry bean with fomesafen applied preemergence. However, other PPO inhibitor herbicides such as flumioxazin caused as much as $34 \%$ visible injury in black, cranberry, kidney, and white bean [21]. Saflufenacil applied PRE caused 51 to $99 \%$ visible injury in adzuki, cranberry, lima, snap, and white bean [23].

Differential sensitivity was seen between market classes of dry beans with some treatments. White bean was more sensitive than cranberry or black bean which were most sensitive than kidney bean to sulfentrazone alone at $280 \mathrm{~g}$ ai/ha or in combination with imazethapyr at $37.5 \mathrm{~g}$ ai/ha at 2 and $4 \mathrm{WAE}$ (Table 2). Other studies have also shown differential sensitivity with soil applied herbicides in dry bean $[2,5,24]$. Market classes of dry beans have different geographic origins and consequently have different gene pool which affects their 
TABLE 2: Percent visual injury 2 and 4 WAE and height for four dry bean types treated with PRE applications of sulfentrazone, imazethapyr, or sulfentrazone plus imazethapyr. Means followed by the same letter within a column (a-d) or row (X-Z) in each section are not significantly different according to Fisher's Protected LSD at $P<0.05^{\mathrm{a}}$.

\begin{tabular}{|c|c|c|c|c|c|c|c|c|c|}
\hline \multirow{3}{*}{$\begin{array}{l}\text { Herbicide treatment (rate in g ai/ha) by variable } \\
\text { Injury } 2 W A E b^{\mathrm{b}}\end{array}$} & \multicolumn{8}{|c|}{ Dry bean type } & \multirow[b]{2}{*}{ SE } \\
\hline & \multicolumn{2}{|c|}{ Black } & \multicolumn{2}{|c|}{ Cranberry } & \multicolumn{2}{|c|}{ Kidney } & \multicolumn{2}{|c|}{ White } & \\
\hline & & & & & & & & & \\
\hline Untreated & $0^{\mathrm{a}}$ & $\mathrm{Z}$ & $0^{\mathrm{a}}$ & $\mathrm{Z}$ & $0^{\mathrm{a}}$ & $\mathrm{Z}$ & $0^{\mathrm{a}}$ & $\mathrm{Z}$ & 0 \\
\hline Sulfentrazone (105) & $1^{\mathrm{ab}}$ & $\mathrm{Z}$ & $1^{\mathrm{ab}}$ & $\mathrm{Z}$ & $1^{\mathrm{ab}}$ & $\mathrm{Z}$ & $3^{\mathrm{bc}}$ & $\mathrm{Z}$ & 0 \\
\hline Sulfentrazone (140) & $3^{\mathrm{b}}$ & $\mathrm{YZ}$ & $2^{\mathrm{b}}$ & $\mathrm{YZ}$ & $2^{\mathrm{bc}}$ & $\mathrm{Z}$ & $6^{c}$ & $\mathrm{Y}$ & 1 \\
\hline Sulfentrazone (280) & $11^{\mathrm{c}}$ & $\mathrm{Y}$ & $11^{\mathrm{c}}$ & $\mathrm{Y}$ & $5^{\mathrm{c}}$ & $\mathrm{Z}$ & $19^{\mathrm{d}}$ & $\mathrm{X}$ & 2 \\
\hline Imazethapyr (37.5) & $1^{\mathrm{ab}}$ & $\mathrm{Z}$ & $1^{\mathrm{ab}}$ & $\mathrm{Z}$ & $1^{\mathrm{ab}}$ & $\mathrm{Z}$ & $1^{\mathrm{ab}}$ & $\mathrm{Z}$ & 1 \\
\hline Sulfentrazone + imazethapyr $(105+37.5)$ & $3^{\mathrm{b}}$ & $\mathrm{Z}$ & $2^{\mathrm{b}}$ & $\mathrm{Z}$ & $2^{\mathrm{bc}}$ & $\mathrm{Z}$ & $4^{\mathrm{bc}}$ & $\mathrm{Z}$ & 1 \\
\hline Sulfentrazone + imazethapyr $(140+37.5)$ & $3^{\mathrm{b}}$ & $\mathrm{Z}$ & $3^{\mathrm{b}}$ & $\mathrm{Z}$ & $2^{\mathrm{bc}}$ & $\mathrm{Z}$ & $6^{\mathrm{c}}$ & $\mathrm{Z}$ & 1 \\
\hline Sulfentrazone + imazethapyr $(280+37.5)$ & $11^{\mathrm{c}}$ & $\mathrm{Y}$ & $10^{\mathrm{c}}$ & $\mathrm{YZ}$ & $5^{\mathrm{c}}$ & $\mathrm{Z}$ & $20^{\mathrm{d}}$ & $\mathrm{X}$ & 2 \\
\hline SE & 1 & & 1 & & 0 & & 1 & & \\
\hline \multicolumn{10}{|l|}{ Injury 4 WAE } \\
\hline Untreated & $0^{\mathrm{a}}$ & $\mathrm{Z}$ & $0^{\mathrm{a}}$ & $\mathrm{Z}$ & $0^{\mathrm{a}}$ & $\mathrm{Z}$ & $0^{\mathrm{a}}$ & $\mathrm{Z}$ & 0 \\
\hline Sulfentrazone (105) & $1^{\mathrm{ab}}$ & $\mathrm{Z}$ & $1^{\mathrm{ab}}$ & $\mathrm{Z}$ & $0^{\mathrm{a}}$ & $\mathrm{Z}$ & $1^{\mathrm{ab}}$ & $\mathrm{Z}$ & 0 \\
\hline Sulfentrazone (140) & $2^{\mathrm{b}}$ & $\mathrm{YZ}$ & $2^{\mathrm{bc}}$ & $\mathrm{YZ}$ & $1^{\mathrm{ab}}$ & $\mathrm{Z}$ & $4^{\mathrm{b}}$ & $\mathrm{Y}$ & 1 \\
\hline Sulfentrazone (280) & $7^{\mathrm{c}}$ & $\mathrm{Y}$ & $7^{\mathrm{d}}$ & $\mathrm{YZ}$ & $4^{\mathrm{b}}$ & $\mathrm{Z}$ & $16^{\mathrm{c}}$ & $\mathrm{X}$ & 2 \\
\hline Imazethapyr (37.5) & $1^{\mathrm{ab}}$ & $\mathrm{Z}$ & $1^{\mathrm{ab}}$ & $\mathrm{Z}$ & $0^{\mathrm{a}}$ & $\mathrm{Z}$ & $1^{\mathrm{ab}}$ & $\mathrm{Z}$ & 0 \\
\hline Sulfentrazone + imazethapyr $(105+37.5)$ & $1^{\mathrm{ab}}$ & $\mathrm{Z}$ & $1^{\mathrm{ab}}$ & $\mathrm{Z}$ & $1^{\mathrm{ab}}$ & $\mathrm{Z}$ & $2^{\mathrm{b}}$ & $\mathrm{Z}$ & 0 \\
\hline Sulfentrazone + imazethapyr $(140+37.5)$ & $3^{\mathrm{b}}$ & $\mathrm{Z}$ & $2^{\mathrm{bc}}$ & $\mathrm{Z}$ & $2^{\mathrm{b}}$ & $\mathrm{Z}$ & $4^{\mathrm{b}}$ & $\mathrm{Z}$ & 1 \\
\hline Sulfentrazone + imazethapyr $(280+37.5)$ & $8^{\mathrm{c}}$ & $\mathrm{Y}$ & $5^{\mathrm{cd}}$ & $\mathrm{YZ}$ & $3^{\mathrm{b}}$ & $\mathrm{Z}$ & $14^{\mathrm{c}}$ & $\mathrm{X}$ & 2 \\
\hline SE & 1 & & 1 & & 0 & & 1 & & \\
\hline \multicolumn{10}{|l|}{ Height } \\
\hline Untreated & $61^{\mathrm{a}}$ & $\mathrm{Z}$ & $52^{\mathrm{a}}$ & Y & $53^{\mathrm{a}}$ & $\mathrm{Y}$ & $58^{\mathrm{a}}$ & $\mathrm{Z}$ & 1 \\
\hline Sulfentrazone (105) & $59^{\mathrm{abc}}$ & $\mathrm{Z}$ & $51^{\mathrm{ab}}$ & $\mathrm{X}$ & $54^{\mathrm{a}}$ & $\mathrm{XY}$ & $55^{\mathrm{a}}$ & $\mathrm{Y}$ & 1 \\
\hline Sulfentrazone (140) & $60^{\mathrm{ab}}$ & $\mathrm{Z}$ & $52^{\mathrm{a}}$ & $\mathrm{Y}$ & $55^{\mathrm{a}}$ & $\mathrm{Y}$ & $56^{\mathrm{a}}$ & $\mathrm{YZ}$ & 1 \\
\hline Sulfentrazone (280) & $57^{\mathrm{bc}}$ & $\mathrm{Z}$ & $50^{\mathrm{ab}}$ & $\mathrm{XY}$ & $54^{\mathrm{a}}$ & $\mathrm{YZ}$ & $50^{\mathrm{b}}$ & $\mathrm{X}$ & 2 \\
\hline Imazethapyr (37.5) & $59^{\mathrm{abc}}$ & $\mathrm{Z}$ & $51^{\mathrm{ab}}$ & $\mathrm{X}$ & $53^{\mathrm{a}}$ & $\mathrm{XY}$ & $55^{\mathrm{a}}$ & $\mathrm{YZ}$ & 1 \\
\hline Sulfentrazone + imazethapyr $(105+37.5)$ & $59^{\mathrm{abc}}$ & $\mathrm{Z}$ & $50^{\mathrm{ab}}$ & $\mathrm{X}$ & $53^{\mathrm{a}}$ & $\mathrm{XY}$ & $55^{\mathrm{a}}$ & $\mathrm{YZ}$ & 1 \\
\hline Sulfentrazone + imazethapyr $(140+37.5)$ & $59^{\mathrm{abc}}$ & $\mathrm{Z}$ & $50^{\mathrm{ab}}$ & $\mathrm{X}$ & $53^{\mathrm{a}}$ & $\mathrm{XY}$ & $55^{\mathrm{a}}$ & $\mathrm{Y}$ & 1 \\
\hline Sulfentrazone + imazethapyr $(280+37.5)$ & $56^{\mathrm{c}}$ & $\mathrm{Z}$ & $49^{\mathrm{b}}$ & Y & $52^{\mathrm{a}}$ & $\mathrm{Y}$ & $48^{\mathrm{b}}$ & $\mathrm{Y}$ & 1 \\
\hline SE & 1 & & 1 & & 1 & & 1 & & \\
\hline
\end{tabular}

${ }^{\mathrm{a}}$ WAE: week after crop emergence; PRE: preemergence.

${ }^{\mathrm{b}}$ Ridgetown 2010 values not included (all values zero, could not be combined with other environments).

tolerance to herbicides [25-27]. Singh et al. [25-27]. studied more than 300 landraces of dry beans from various geographical and ecological regions of domestication of dry bean in America (Mexico, Nicaragua, El Salvador, Honduras, Costa Rica, Dominican Republic, Columbia, Argentina and Brazil) and concluded that origin determines distinctive agronomic traits, morphology, adaptation and disease resistance in dry bean.

3.2. Shoot Dry Weight and Plant Height. Sulfentrazone and imazethapyr alone or in combination with each other at doses evaluated had no adverse effect on shoot dry weight of black, cranberry, kidney, and white bean (Table 1). In other studies, sulfentrazone applied PRE at $420 \mathrm{~g} \mathrm{ha}^{-1}$ did not have any effect on the shoot dry weight of black, brown, cranberry, kidney, otebo, pinto, white, and yellow eye beans but, at
$840 \mathrm{~g} \mathrm{ha}^{-1}$, decreased shoot dry weight 30 to $40 \%$ [19]. Other PPO inhibitor herbicides such as saflufenacil applied PRE have been shown to reduce shoot dry weight 92 to $99 \%$ in adzuki, cranberry, lima, snap, and white bean [23].

Plant height is important in dry bean production as shorter plants can have greater seed loss at the cutter bar of the combine during harvest. Sulfentrazone at 105 and $140 \mathrm{~g}$ ai/ha and imazethapyr at $37.5 \mathrm{~g}$ ai/ha alone or in combination with each other had no adverse effect on height of black, cranberry, kidney, and white bean (Table 2). Sulfentrazone at $280 \mathrm{~g}$ ai/ha decreased height of black bean $7 \%$ and white bean $14 \%$ but had no adverse effect on the height of cranberry and kidney bean compared to the untreated weed free control. Sulfentrazone at $280 \mathrm{~g}$ ai/ha plus imazethapyr at $37.5 \mathrm{~g}$ ai/ha decreased height of black bean $8 \%$, cranberry bean $6 \%$, and white bean $14 \%$ but had no adverse effect on the height of kidney 
bean compared to the untreated weed free control (Table 2). Differential sensitivity was seen between market classes of dry beans with some treatments. Black and white bean were generally more sensitive to sulfentrazone than cranberry and kidney bean; however, results were not always statistically significant (Table 2).

In other studies, sulfentrazone applied PRE at 420 and $840 \mathrm{~g} \mathrm{ha}^{-1}$ had no adverse effect on the height of black, brown, cranberry, kidney, otebo, pinto, white, and yellow eye bean. Imazethapyr applied PRE caused no adverse effect on the height of cranberry and kidney beans but reduced height of black and white beans as much as 40\% [28-30]. PPO inhibitor herbicides such as flumioxazin PRE reduced the height of black bean $23 \%$ and white beans $28 \%$ but had no effect on the height of cranberry and kidney beans [21]. Saflufenacil applied PRE reduced plant height 25 to $93 \%$ in adzuki, cranberry, lima, snap, and white bean [23].

3.3. Seed Moisture Content and Yield. Sulfentrazone at 105, 140 , and $280 \mathrm{~g}$ ai/ha, applied alone or in combination with imazethapyr at $37.5 \mathrm{~g}$ ai/ha, caused no adverse effect on the seed moisture content and yield of black, cranberry, kidney, and white bean (Table 1). In other studies sulfentrazone applied preemergence at 420 to $840 \mathrm{~g}$ ai/ha caused 26 to $52 \%$ seed yield reduction in black, cranberry, otebo, and white bean [19]. Other PPO inhibitor herbicides such as flumioxazin reduced seed yield of black and white bean 20 to 30\% but had no adverse effect on yield of cranberry and kidney bean [21]. Saflufenacil applied PRE decreased seed yield 56 to 99\% in adzuki, cranberry, lima, snap, and white beans [23]. Other PPO inhibitor herbicides such as fomesafen had little effect on the seed yield of dry bean $[5,20,22]$.

\section{Conclusions}

Based on this research, sulfentrazone applied PRE at the rates up to $140 \mathrm{~g}$ ai/ha alone or in combination with imazethapyr at $37.5 \mathrm{~g}$ ai/ha has potential to be used in black, cranberry, kidney, and white bean under Ontario environmental condition. There is a slight differential sensitivity between dry bean market classes to sulfentrazone. Sulfentrazone PRE caused slightly greater injury in black and white bean compared to cranberry and kidney bean but crop injury at rates up to $140 \mathrm{~g}$ ai/ha was minimal with no adverse effect on plant height, shoot dry weight, seed moisture content, and yield under the environmental condition in this study. Availability of sulfentrazone alone or in combination with imazethapyr for weed management in dry bean production would provide growers with a new herbicide option for the control of troublesome weeds such as common ragweed, common lambsquarters, common pigweed, and other annual broadleaf weeds.

\section{Conflict of Interests}

The authors declare that there is no conflict of interests regarding the publication of this paper.

\section{Acknowledgments}

The authors would like to acknowledge Todd Cowan for his expertise and technical assistance in these studies. Funding for this project was provided by the Ontario White Bean Producers, Ontario Coloured Bean Growers Association, and the CanAdvance program of Agricultural Adaptation Council.

\section{References}

[1] N. R. Arnold, W. M. Murray, J. E. Gregory, and D. Smeal, "Weed control in pinto beans (Phaseolus vulgaris) with imazethapyr combinations," Weed Technology, vol. 7, pp. 361-364, 1993.

[2] T. A. Bauer, K. A. Renner, D. Penner, and J. D. Kelly, "Pinto bean (Phaseolus vulgaris) varietal tolerance to imazethapyr," Weed Science, vol. 43, no. 3, pp. 417-424, 1995.

[3] R. E. Blackshaw and R. Esau, "Control of annual broadleaved weeds in pinto beans (Phaseolus vulgaris)," Weed Technology, vol. 5, pp. 532-538, 1991.

[4] C. P. Urwin, R. G. Wilson, and D. A. Mortensen, "Response of dry edible bean (Phaseolus vulgaris) cultivars to four herbicides," Weed Technology, vol. 10, no. 3, pp. 512-518, 1996.

[5] R. G. Wilson and S. D. Miller, "Dry edible bean (Phaseolus vulgaris) responses to imazethapyr," Weed Technology, vol. 5, pp. 22-26, 1991.

[6] V. S. Malik, C. J. Swanton, and T. E. Michaels, "Interaction of white bean (Phaseolus vulgaris) cultivars, row spacing, and seeding density with annual weeds," Weed Science, vol. 41, pp. 62-68, 1993.

[7] R. G. Wilson, "Wild proso millet (Panicum miliaceum) interference in dry beans (Phaseolus vulgaris)," Weed Science, vol. 41, no. 4, pp. 607-610, 1993.

[8] R. L. Zimdahl, Weed-Crop Competition, International Plant Protection Center, Oregon State University, Corvallis, Ore, USA, 1980.

[9] I. J. Bassettand and D. B. Munro, "The biology of Canadian weeds. 67. Solanum ptycanthum Dun., S. nigrum L., and S. sarrachoides Sendt," Canadian Journal of Plant Science, vol. 65, pp. 401-414, 1985.

[10] A. G. Ogg and B. S. Rogers, "Taxonomy, distribution, biology, and control of black nightshade (Solanum nigrum) and related species in the United States and Canada. Rev.", Weed Science, vol. 4, pp. 25-58, 1989.

[11] J. W. Niekamp, Weed management with sulfentrazone and flumioxazin in no-tillage soybean [M.S. thesis], University of Missouri, Columbia, Mo, USA, 1998.

[12] J. W. Niekamp and W. G. Johnson, "Weed management with sulfentrazone and flumioxazin in no-tillage soyabean (Glycine max)," Crop Protection, vol. 20, no. 3, pp. 215-220, 2001.

[13] S. Taylor-Lovell, L. M. Wax, and R. Nelson, "Phytotoxic response and yield of soybean (Glycine max) varieties treated with sulfentrazone and flumioxazin," Weed Technology, vol. 15, no. 1, pp. 95-102, 2001.

[14] S. A. Senseman, Herbicide Handbook, Weed Science Society of America, Champaign, Ill, USA, 9th edition, 2007.

[15] J. W. Niekamp, W. G. Johnson, and R. J. Smeda, "Broadleaf weed control with sulfentrazone and flumioxazin in no-tillage soybean (Glycine max)," Weed Technology, vol. 13, no. 2, pp. 233238, 1999. 
[16] B. Hartzler, "Sulfentrazone and flumioxazin injury to soybean," Iowa Stat University, 2004, http://www.weeds.iastate.edu/ mgmt/2004/ppoinjury.shtml.

[17] M. J. Vangessel, D. W. Monks, and Q. R. Johnson, "Herbicides for potential use in lima bean (Phaseolus lunatus) production," Weed Technology, vol. 14, no. 2, pp. 279-286, 2000.

[18] K. A. Renner and G. E. Powell, "Responses of navy bean (Phaseolus vulgaris) and wheat (Triticum aestivum) grown in rotation to clomazone, imazethapyr, bentazon, and acifluorfen," Weed Science, vol. 40, pp. 127-133, 1992.

[19] S. Hekmat, C. Shropshire, N. Soltani, and P. H. Sikkema, "Responses of dry beans (Phaseolus vulgaris L.) to sulfentrazone," Crop Protection, vol. 26, no. 4, pp. 525-529, 2007.

[20] P. H. Sikkema, C. Shropshire, and N. Soltani, "Response of dry bean to pre-plant incorporated and pre-emergence applications of $S$-metolachlor and fomesafen," Crop Protection, vol. 28, no. 9, pp. 744-748, 2009.

[21] N. Soltani, S. Bowley, and P. H. Sikkema, "Responses of dry beans to flumioxazin," Weed Technology, vol. 19, no. 2, pp. 351358, 2005.

[22] R. G. Wilson, "Response of dry bean and weeds to fomesafen and fomesafen tank mixtures," Weed Technology, vol. 19, no. 1, pp. 201-206, 2005.

[23] N. Soltani, C. Shropshire, and P. H. Sikkema, "Sensitivity of leguminous crops to saflufenacil," Weed Technology, vol. 24, no. 2, pp. 143-146, 2010.

[24] K. Poling, Dry edible bean responses to dimethenamid and metolachlor [M.S. thesis], Michigan State University, East Lansing, Mich, USA, 1999.

[25] S. P. Singh, P. Gepts, and D. G. Debouck, "Races of common bean (Phaseolus vulgaris, Fabaceae)," Economic Botany, vol. 45, no. 3, pp. 379-396, 1991.

[26] S. P. Singh, J. A. Gutierrez, A. Molina, C. Urrea, and P. Gepts, "Genetic diversity in cultivated common bean: II. Marker-based analysis of morphological and agronomic traits," Crop Science, vol. 31, pp. 23-29, 1991.

[27] S. P. Singh, R. Nodari, and P. Gepts, "Genetic diversity in cultivated common bean: I. Allozymes," Crop Science, vol. 31, pp. 19-23, 1991.

[28] N. Soltani, C. Shropshire, T. Cowan, and P. Sikkema, “Tolerance of cranberry beans (Phaseolus vulgaris) to soil applications of $S$-metolachlor and imazethapyr," Canadian Journal of Plant Science, vol. 83, no. 3, pp. 645-648, 2003.

[29] N. Soltani, C. Shropshire, T. Cowan, and P. Sikkema, "Tolerance of black beans (Phaseolus vulgaris) to soil applications of $S$ metolachlor and imazethapyr," Weed Technology, vol. 18, no. 1, pp. 111-118, 2004.

[30] P. Sikkema, N. Soltani, C. Shropshire, and T. Cowan, "Sensitivity of kidney beans (Phaseolus vulgaris) to soil applications of $S$-metolachlor and imazethapyr," Canadian Journal of Plant Science, vol. 84, no. 1, pp. 405-407, 2004. 


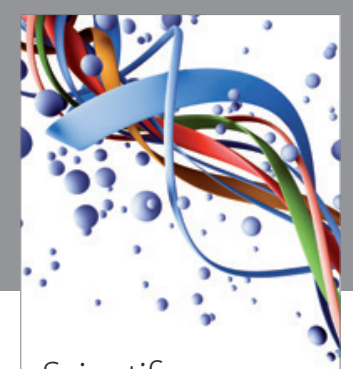

Scientifica
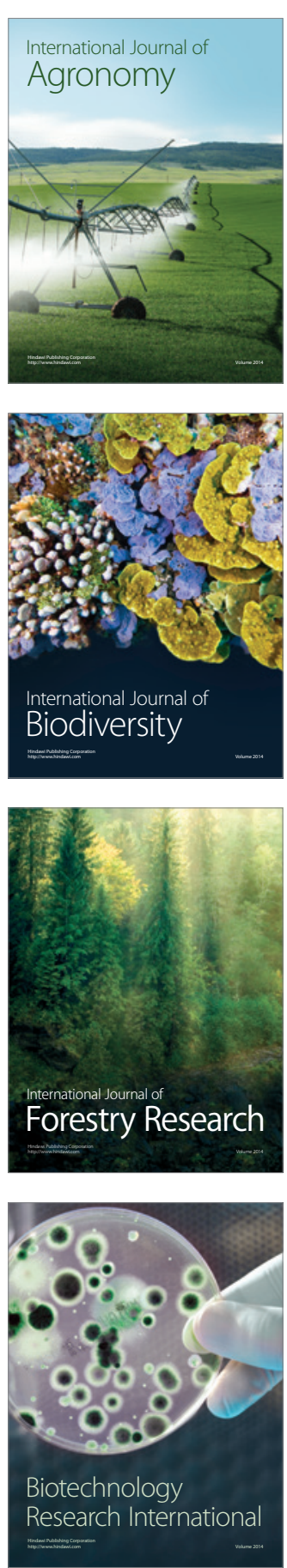
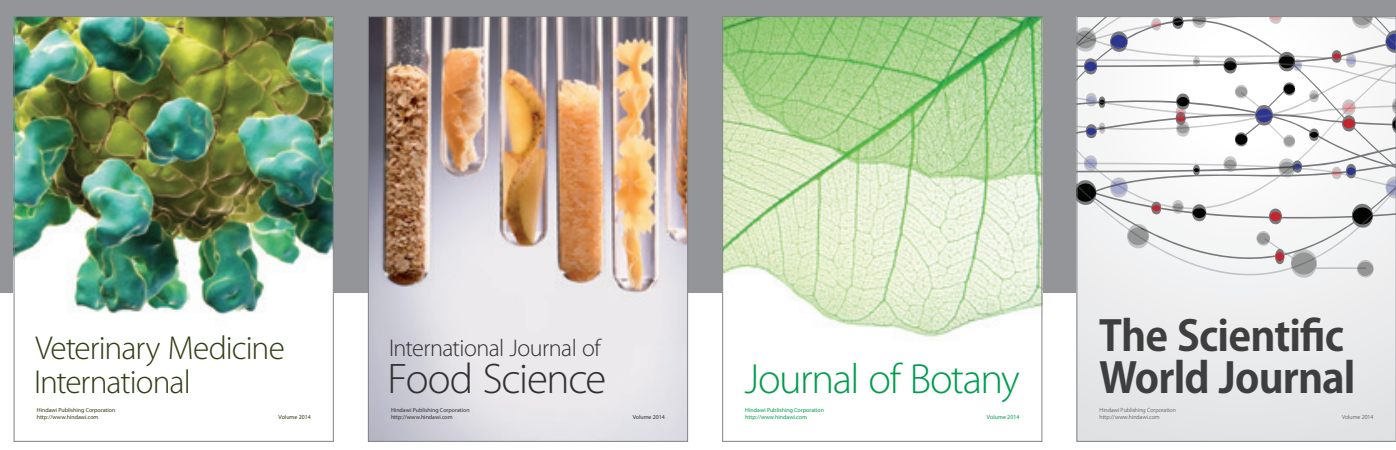

The Scientific World Journal
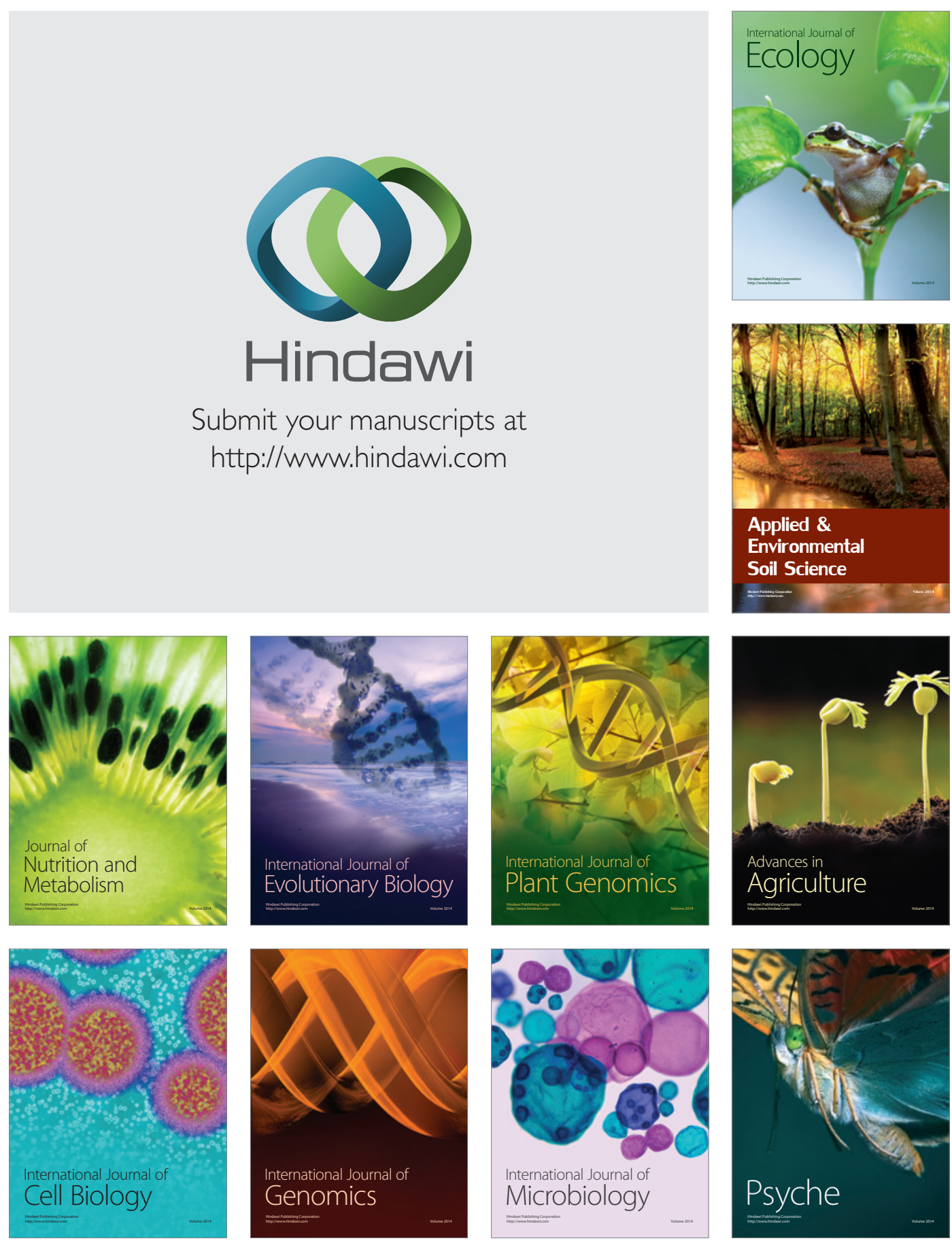